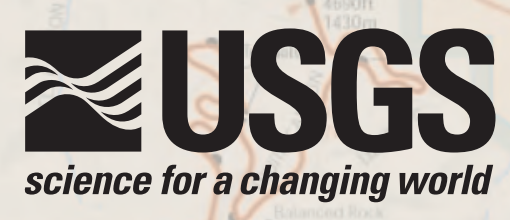

\title{
Characterization of Petroleum Residue in the Entrada Sandstone, Colorado National Monument
}

Open-File Report 2007-1360

U.S. Department of the Interior U.S. Geological Survey 


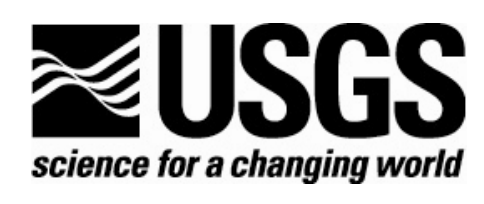

\section{Characterization of Petroleum Residue in the Entrada Sandstone, Colorado National Monument}

By Paul G. Lillis and J. David King

Open-File Report 2007-1360

U.S. Department of the Interior U.S. Geological Survey 


\title{
U.S. Department of the Interior DIRK KEMPTHORNE, Secretary
}

\author{
U.S. Geological Survey \\ Mark D. Myers, Director
}

U.S. Geological Survey, Reston, Virginia 2007

For product and ordering information:

World Wide Web: http://www.usgs.gov/pubprod

Telephone: 1-888-ASK-USGS

For more information on the USGS - the Federal source for science about the Earth, its natural and living resources, natural hazards, and the environment:

World Wide Web: http://www.usgs.gov

Telephone: 1-888-ASK-USGS

Any use of trade, product, or firm names is for descriptive purposes only and does not imply endorsement by the U.S. Government.

Although this report is in the public domain, permission must be secured from the individual copyright owners to reproduce any copyrighted material contained within this report.

Suggested citation:

Lillis, P.G., and King, J.D., 2007, Characterization of petroleum residue in the Entrada

Sandstone, Colorado National Monument: U.S. Geological Survey Open-File Report 2007-1360,

$18 \mathrm{p}$. 


\title{
Characterization of Petroleum Residue in the Entrada Sandstone, Colorado National Monument
}

\author{
By Paul G. Lillis and J. David King
}

\section{Introduction}

As part of the U.S. Geological Survey's (USGS) petroleum resource assessment of the Uinta-Piceance Province, Colorado and Utah, in 2000 (USGS Uinta-Piceance Assessment Team, 2003), some 170 oils, oil stains, and oil seeps were geochemically characterized and divided into genetic types (Lillis and others, 2003). Recognized oil types include Minturn, Phosphoria, Grassy Trail Creek, Mancos, Mesaverde, and Green River. Subsequent to that study, the existence and general locality of petroleum residue in the Middle Jurassic Entrada Sandstone in Colorado National Monument (CNM) was brought to the attention of the authors (Scott and others, 2001). Because the analysis of such non-commercial petroleum deposits commonly yields valuable regional resource-trend information, we collected and characterized the reported CNM petroleum residue and compared the results with identified oil types in the Uinta-Piceance Province.

Three samples of Entrada Sandstone with petroleum residue (table 1) were collected near Little Park Road along the south edge of the CNM in sec.20, T.12S., R.101W. (fig. 1). The approximate extent of the petroleum staining was determined by field testing with solvent, and the stains appear to be restricted to the upper part of the "board beds" unit (informal name, Scott and others, 2001) of the Entrada Sandstone between the two fault traces of the Glade Park fault (figs. 2, 3). 


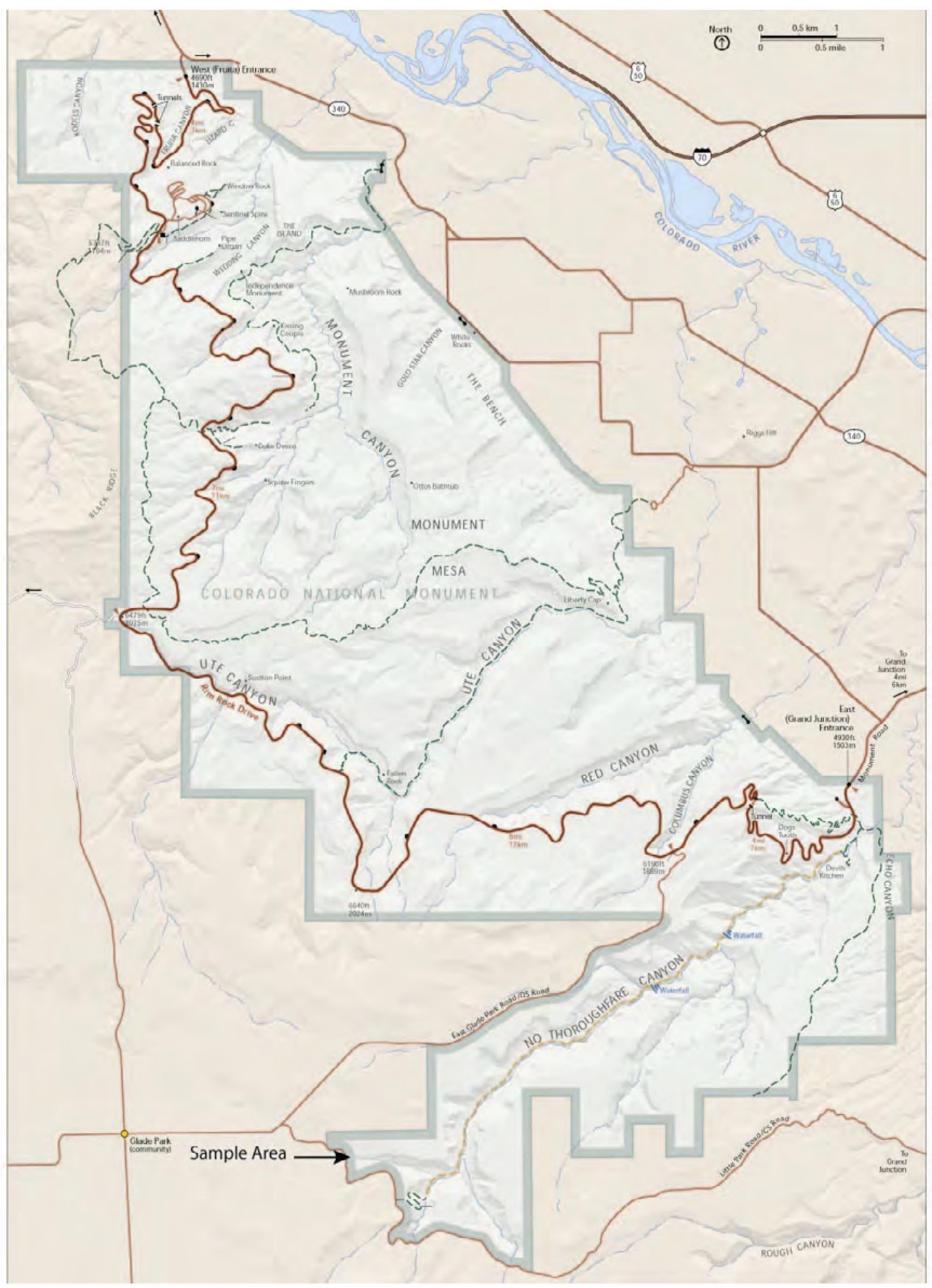

Figure 1. Map of the Colorado National Monument showing the petroleum residue sample area (modified from the National Park Service). 


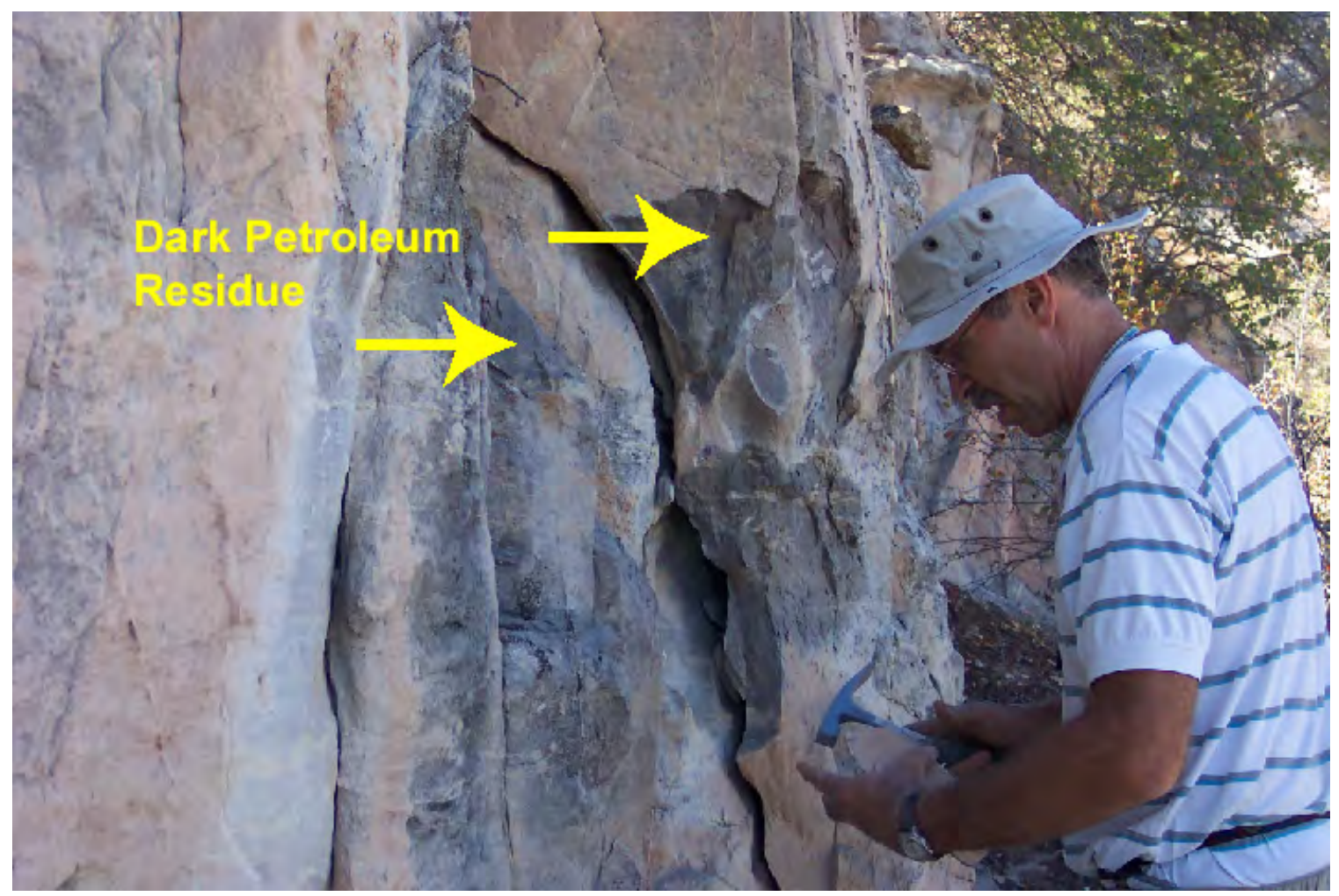

Figure 2. Dark petroleum residue is observed in the pore space of the upper part of the "board beds" unit (informal name, Scott and others, 2001) of the Entrada Sandstone. 


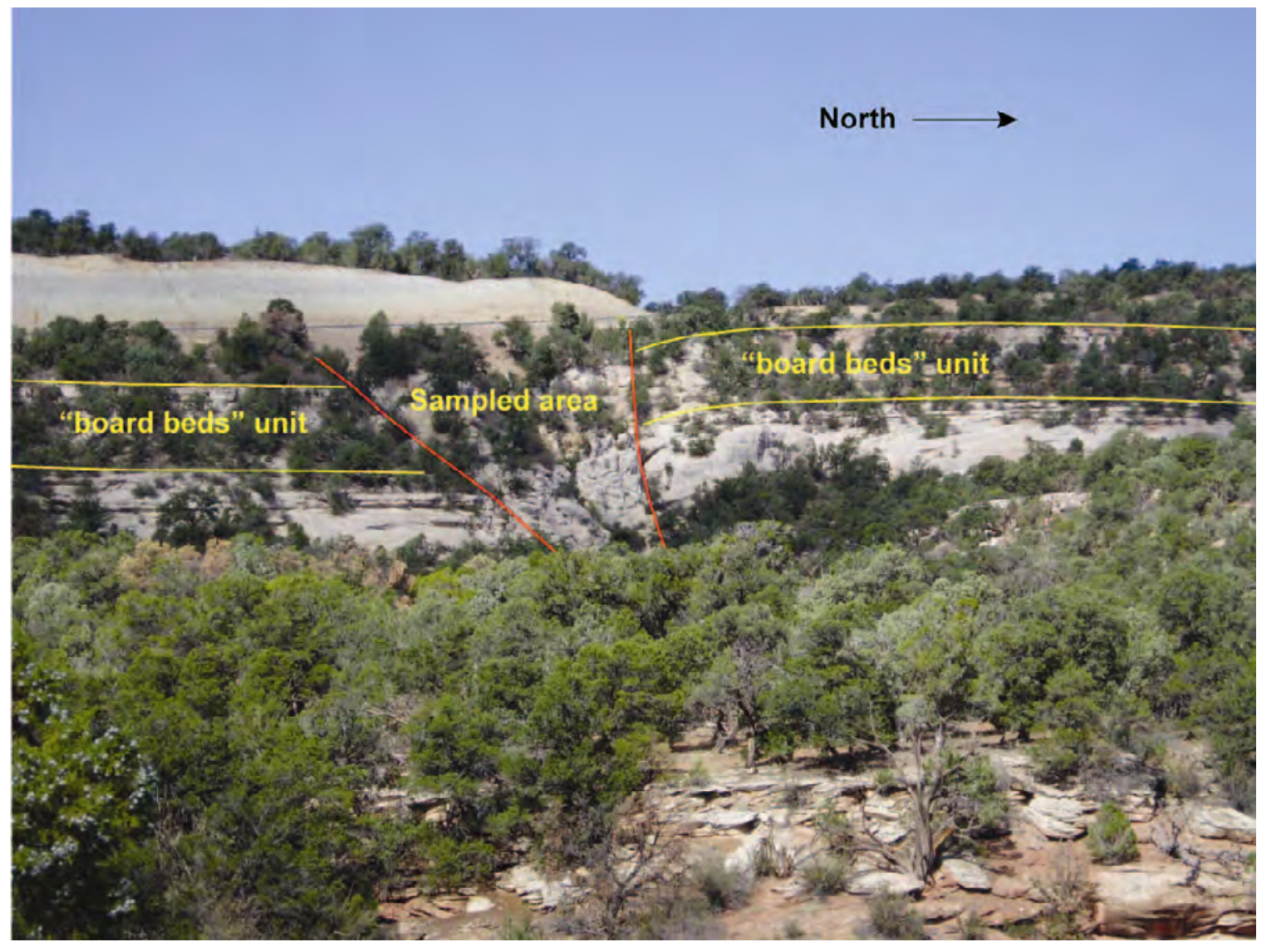

Figure 3. Photograph of outcrop at head of No Thoroughfare Canyon, looking west, showing sampled area in the "board beds" unit of the Entrada Sandstone between south and north fault traces of the Glade Park Fault (in red).

Table 1. Bulk geochemical data of petroleum residue in the Jurassic Entrada Formation, Colorado National Monument.

[EOM, extractable organic matter (ppm, weight/weight); S/A, saturated hydrocarbons/aromatic hydrocarbons ratio; $\mathrm{S}$ wt $\%$, sulfur weight percent; $\delta^{13} \mathrm{Cs}$, stable carbon isotopes, $\mathrm{C}_{15+}$ saturated hydrocarbons, per mil, $\mathrm{PDB} ; \delta^{13} \mathrm{Ca}$, stable carbon isotopes, $\mathrm{C}_{15+}$ aromatic hydrocarbons, per mil, PDB; $\mathrm{CV}$, canonical variable (Sofer, 1984) equal to $-2.53 \delta^{13} \mathrm{Cs}+2.22 \delta^{13} \mathrm{Ca}-11.65 ; \delta^{13} \mathrm{Cb}$, stable carbon isotopes, $\mathrm{C}_{15+}$ whole extract, per mil, PDB; ---, no data]

Sample No. Sample Name $\quad$ EOM $\quad$ S/A $\quad$ S wt $\% \quad \delta^{13} \mathrm{Cs} \quad \delta^{13} \mathrm{Ca} \quad \mathrm{CV} \quad \delta^{13} \mathrm{Cb}$

$\begin{array}{ccccccccc}04039-001 & \text { 04PL0915-001 } & 3791 & 3.0 & 1.46 & -27.92 & -27.46 & -1.97 & -27.89 \\ 04039-002 & \text { 04PL0915-002 } & 2831 & 3.9 & 1.64 & -27.57 & -27.47 & -2.88 & --- \\ 04039-003 & \text { 04PL0915-003 } & 5802 & --- & --- & --- & --- & --- & ---\end{array}$




\section{Methods}

Petroleum residue was extracted from the rock samples using a Soxhlet extraction apparatus with chloroform as a solvent. The extracts were separated into asphaltene and maltene fractions by precipitation in excess volumes of $i s o$-octane followed by centrifugation and filtration (asphaltenes are the precipitate). Saturated hydrocarbon, aromatic hydrocarbon, and polar hydrocarbon fractions were separated from the maltene fraction by column chromatography with alumina-silica columns and successive elution with iso-octane, benzene, and benzene-methanol azeotrope, respectively. The stable carbon isotope values $\left(\delta^{13} \mathrm{C}\right)$ of the $\mathrm{C}_{15}+$ saturated and aromatic hydrocarbon fractions of the extracts were determined using a Carlo Erba elemental analyzer (EA) interfaced to a Micromass Optima continuous-flow isotope ratio mass spectrometer (IRMS). Sample aliquots were introduced into the EA furnace heated to about $1,020^{\circ} \mathrm{C}$, and flash combusted in a quartz combustion tube filled with oxygen. The evolved $\mathrm{CO}_{2}$ passed through chromium oxide (to complete oxidation), copper granules (reducing agent), and anhydrone (to remove water) before being swept into the IRMS with a helium carrier gas. The results are expressed in the delta $(\delta)$ notation that represents the deviation of the ${ }^{13} \mathrm{C} /{ }^{12} \mathrm{C}$ ratio in parts per thousand (per mil, or \%o) relative to the Peedee belemnite (PDB) standard. The sulfur content of the extracts was determined by combustion using a Carlo Erba 1110 elemental analyzer.

The maltene fractions of the extracts were analyzed by gas chromatography and gas chromatography/mass spectrometry. Gas chromatography of the extract was performed on a Hewlett Packard 6890 gas chromatograph with a DB-1 (bonded phase 100 percent dimethylpolysiloxane, $0.25-\mu \mathrm{m}$ thickness) capillary column (60 $\mathrm{m}$ long by $0.32-\mathrm{mm}$ inner diameter), splitless injection, flame ionization detector (FID), and programmed heating 
$\left(40^{\circ} \mathrm{C}\right.$ to $330^{\circ} \mathrm{C}$ at $4.5^{\circ} \mathrm{C} /$ minute, held at $330^{\circ} \mathrm{C}$ for $15 \mathrm{~min}$ ). Biological marker (biomarker) distributions of the extracts were determined on a Hewlett-Packard 6890 gas chromatograph interfaced with a JEOL GCmate magnetic sector mass spectrometer using selected ion monitoring $(\mathrm{SIM})$ at mass-to-charge $(\mathrm{m} / \mathrm{z})$ ratios of $191.1800,217.1956,231.1174$, and 253.1956. The gas chromatography analysis used a DB-1701 (bonded phase 14 percent cyanopropylphenyl, 86 percent dimethylpolysiloxane copolymer, $0.25-\mu \mathrm{m}$ thickness) capillary column (60 m long by 0.31-mm inner diameter), splitless injection, and an oven temperature program of 50 to $150^{\circ} \mathrm{C}$ at $50^{\circ} \mathrm{C} / \mathrm{min}, 150$ to $300^{\circ} \mathrm{C}$ at $3^{\circ} \mathrm{C} / \mathrm{min}$, and a final hold time of 9 min at $300^{\circ} \mathrm{C}$.

\section{Results}

The results of the bulk geochemical analyses are listed in table 1. All three Entrada samples contain high concentrations of petroleum residue (extractable organic matter $>2500$

ppm). Figure 4 shows saturated hydrocarbon $\delta^{13} \mathrm{C}$ vs. aromatic hydrocarbon $\delta^{13} \mathrm{C}$ isotope ratios for the CNM samples in comparison with other crude oils, oil seeps, and petroleum stains throughout the Uinta-Piceance Province. Gas chromatograms of the extracts (fig.5) show large unresolved "humps" and resolved biomarker peaks (between 40 and $70 \mathrm{~min}$ ), but are missing the regular series of normal alkane peaks that are observed in most petroleum.

Molecular biomarker parameters are listed in table 2. Figures 6 and 7 are the mass chromatograms for $\mathrm{m} / \mathrm{z} 191.1800$ and 217.1956, representing polycyclic terpanes and steranes, respectively. Figures 8 and 9 are a comparison of the terpane and sterane distributions, respectively, between the least altered CNM sample (04039-001) and typical production crude oils representing Phosphoria and Mancos oil types. 


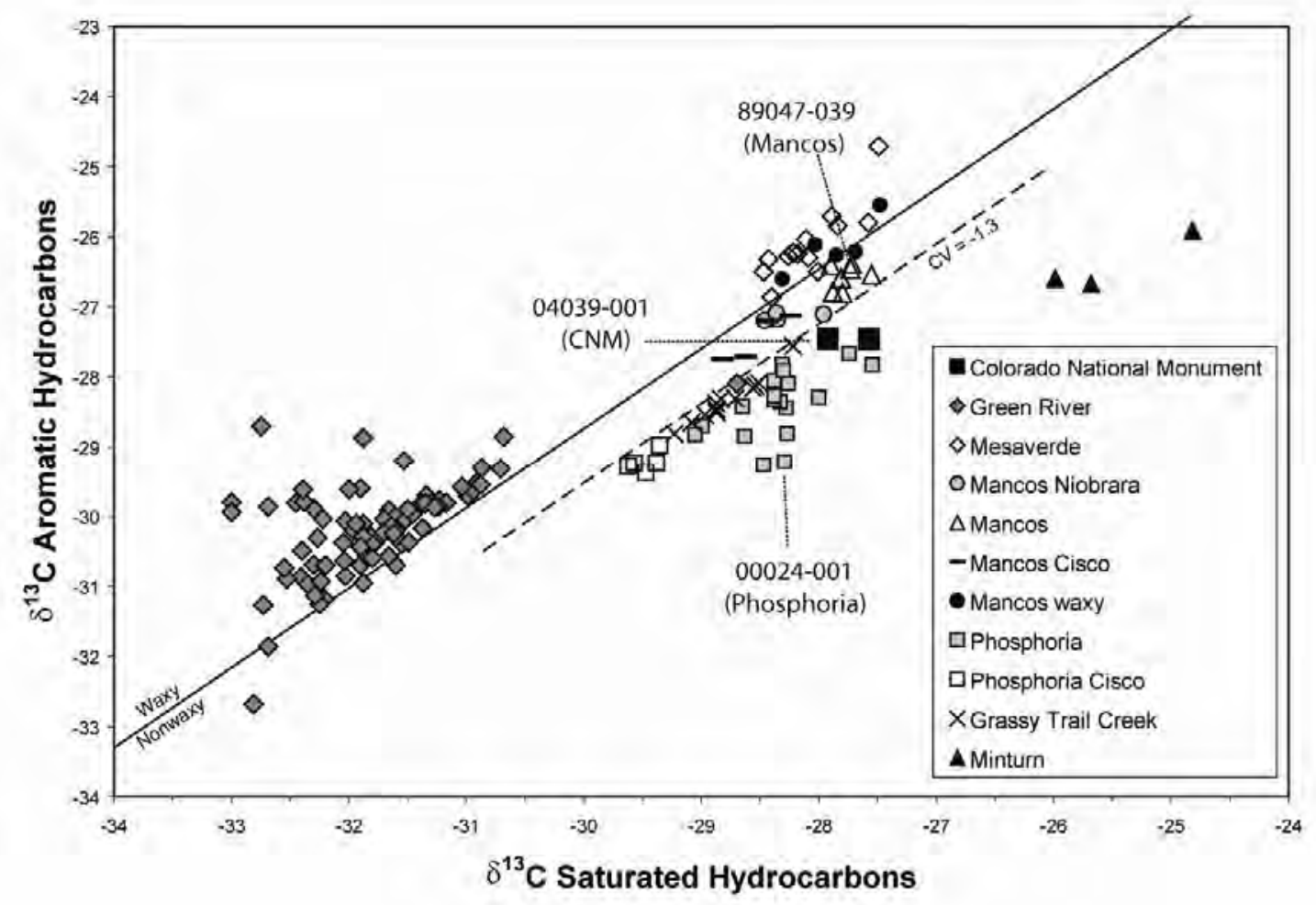

Figure 4. Stable carbon isotope analyses of petroleum residue extracts from the Entrada Sandstone in Colorado National Monument (CNM), as well as production crude oils, oil stains, and oil seeps from within the Uinta-Piceance Province (Lillis and others, 2003). Solid line distinguishes waxy from nonwaxy oils (Sofer, 1984). Dashed line (canonical variable (CV) equal to -1.3) separates Cretaceous from Paleozoic oils (Lillis and others, 2003). Numbers refer to sample numbering system. 


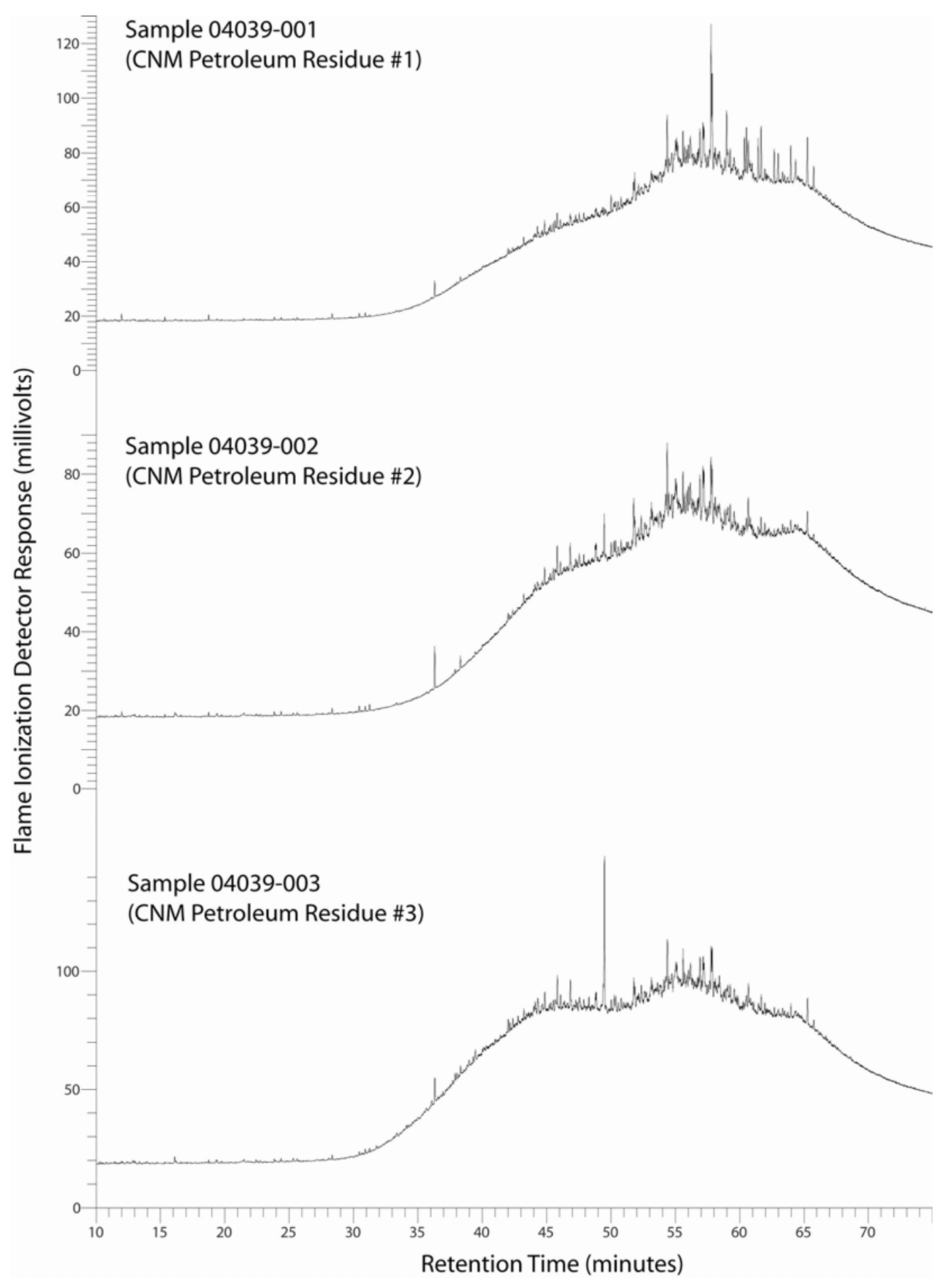

Figure 5. Gas chromatograms of petroleum residue extracts from the Entrada Sandstone in Colorado National Monument (CNM). Significant biodegradation is indicated by the lack of a series of regularly spaced $n$-hydrocarbon peaks and by the presence of a large unresolved "hump". Sample 04039-001 has the best resolved biomarker peaks (retention time range 40-70 $\mathrm{min})$. 
Table 2. Selected biomarker ratios of petroleum residue in the Jurassic Entrada Formation, Colorado National Monument, and two representative crude oils from the Uinta-Piceance Province. Sample 89047-039 is Mancos oil type, and 00024-001 is Phosphoria oil type (Lillis and others, 2003).

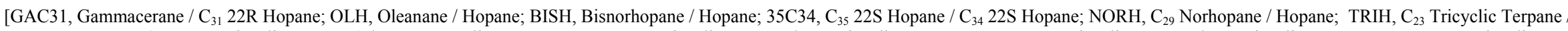
Hopane; C26TET, $\left(\mathrm{C}_{26} \mathrm{~S}+\mathrm{R}\right.$ Tricyclic Terpanes) / $\mathrm{C}_{24}$ Tetracyclic Terpane; 19_23, $\mathrm{C}_{19}$ Tricyclic Terpane / $\mathrm{C}_{23}$ Tricyclic Terpane; 24_23, $\mathrm{C}_{24}$ Tricyclic Terpane / $\mathrm{C}_{23}$ Tricyclic Terpane; 26_25, $\mathrm{C}_{26}$ Tricyclic Terpane / $\mathrm{C}_{25}$ Tricyclic Terpane by Peak Area; 27ST, $\mathrm{C}_{27} \alpha \alpha \alpha$ 20R Sterane / $\mathrm{C}_{27}+\mathrm{C}_{28}+\mathrm{C}_{29} \alpha \alpha \alpha$ 20R Steranes; 28ST, $\mathrm{C}_{28} \alpha \alpha \alpha$ 20R Sterane / $\mathrm{C}_{27}+\mathrm{C}_{28}+\mathrm{C}_{29} \alpha \alpha \alpha 20 \mathrm{R}$ Steranes; 29ST, $\mathrm{C}_{29} \alpha \alpha \alpha$ 20R Sterane/ $\mathrm{C}_{27}+\mathrm{C}_{28}+\mathrm{C}_{29} \alpha \alpha \alpha$ 20R Steranes; S1S6, $\mathrm{C}_{27} \beta \alpha$ 20S Diasterane / $\mathrm{C}_{27} \alpha \alpha \alpha$ 20R Sterane; 29SR, $\mathrm{C}_{29} \alpha \alpha \alpha$ 20S Sterane)/( $\mathrm{C}_{29} \alpha \alpha \alpha$ 20S $+20 \mathrm{R}$ Sterane); 29BB, $\mathrm{C}_{29} \alpha \beta \beta 20 \mathrm{R}$ Sterane) / (C $29 \beta \beta 20 \mathrm{R}$ Sterane + $\alpha \alpha \alpha$ 20R Sterane) ]

\begin{tabular}{|c|c|c|c|c|c|c|c|c|c|c|c|c|c|c|c|c|}
\hline Sample No. & GAC31 & $\mathrm{OLH}$ & BISH & $35 \mathrm{C} 34$ & NORH & TRIH & 26TET & $19 \_23$ & $24 \_23$ & $26 \_25$ & $27 \mathrm{ST}$ & $28 \mathrm{ST}$ & $29 \mathrm{ST}$ & S1S6 & 29SR & $29 \mathrm{BB}$ \\
\hline 04039-002 & 2.01 & 0.60 & 0.34 & 1.89 & 1.66 & 1.55 & 2.83 & 0.02 & 0.93 & 0.96 & 0.38 & 0.20 & 0.41 & 1.50 & 0.50 & 0.64 \\
\hline 04039-003 & 1.58 & 0.59 & 0.30 & 1.82 & 1.90 & 2.05 & 3.27 & 0.03 & 0.85 & 0.79 & 0.29 & 0.19 & 0.52 & 2.78 & 0.55 & 0.66 \\
\hline 89047-039 & 0.3 & 0.1 & 0.07 & 0.64 & 0.43 & 0.15 & 0.07 & 0.47 & 0.8 & 0.03 & 0.27 & 0.35 & 0.38 & 2.12 & 0.51 & 0.55 \\
\hline
\end{tabular}




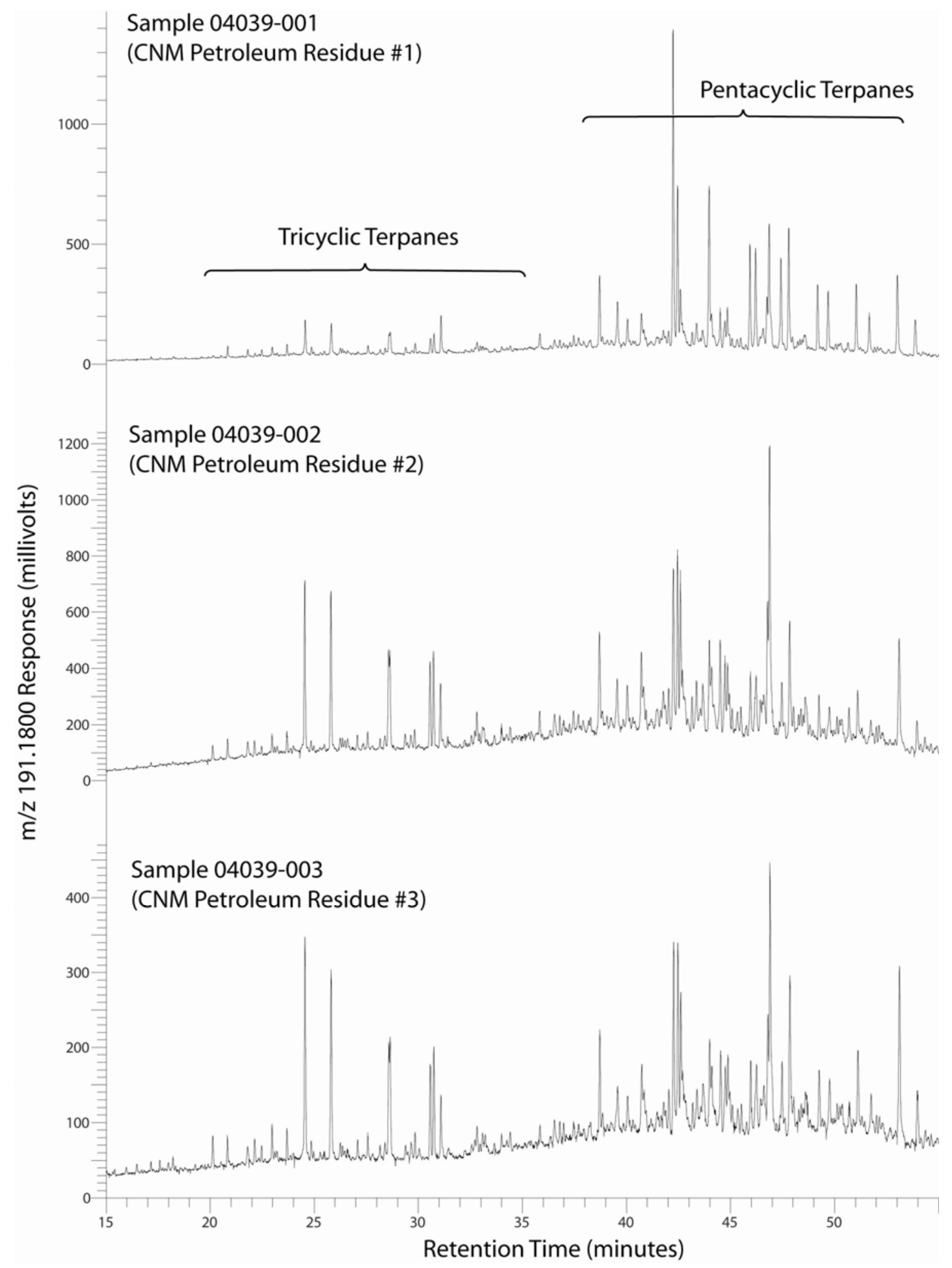

Figure 6. Terpane mass chromatograms of petroleum residue extracts from the Entrada Sandstone in Colorado National Monument (CNM). Sample 04039-001 has the best resolved pentacyclic terpane peaks. 


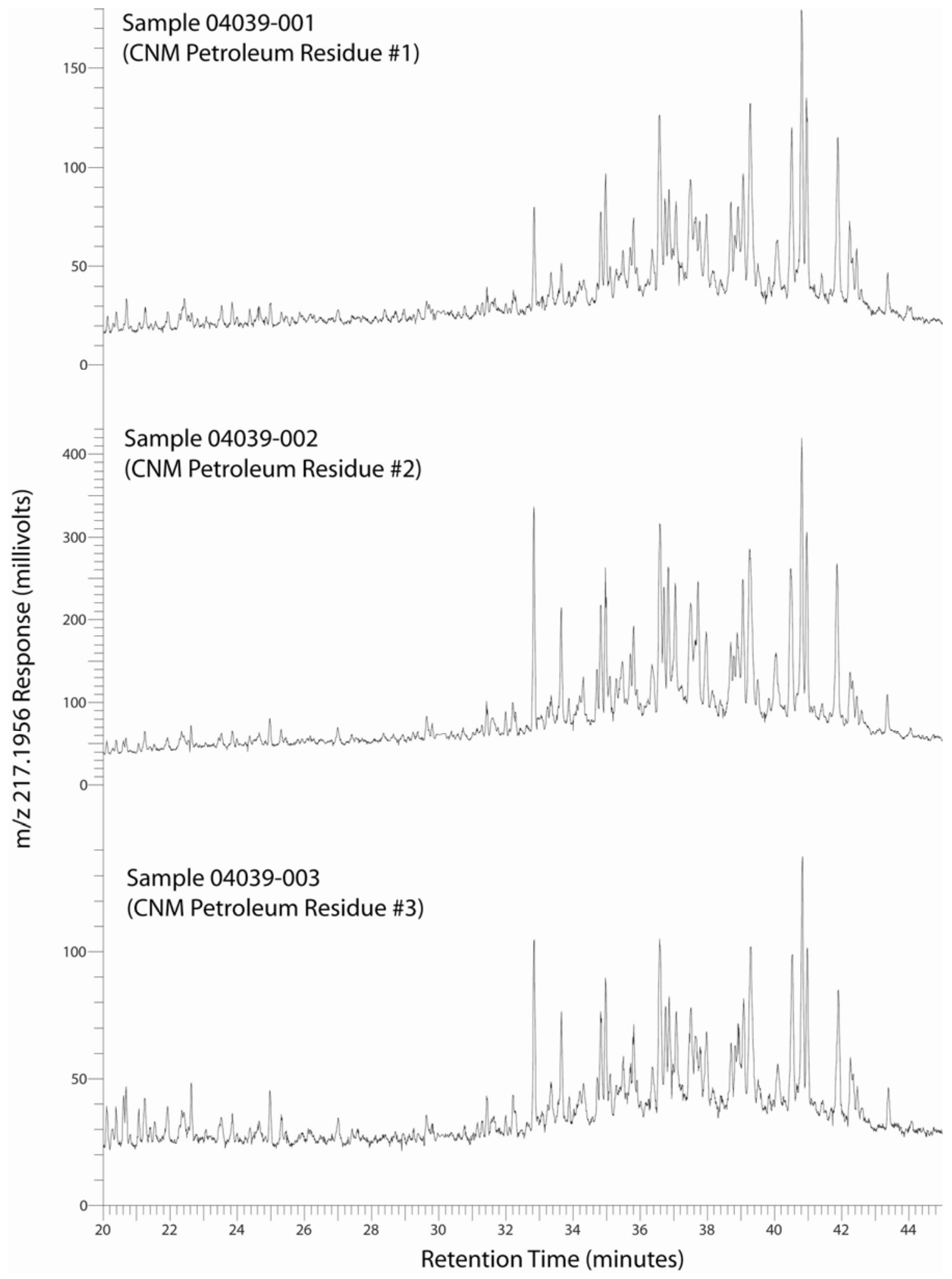

Figure 7. Sterane mass chromatograms of petroleum residue extracts from the Entrada Sandstone in Colorado National Monument (CNM). 


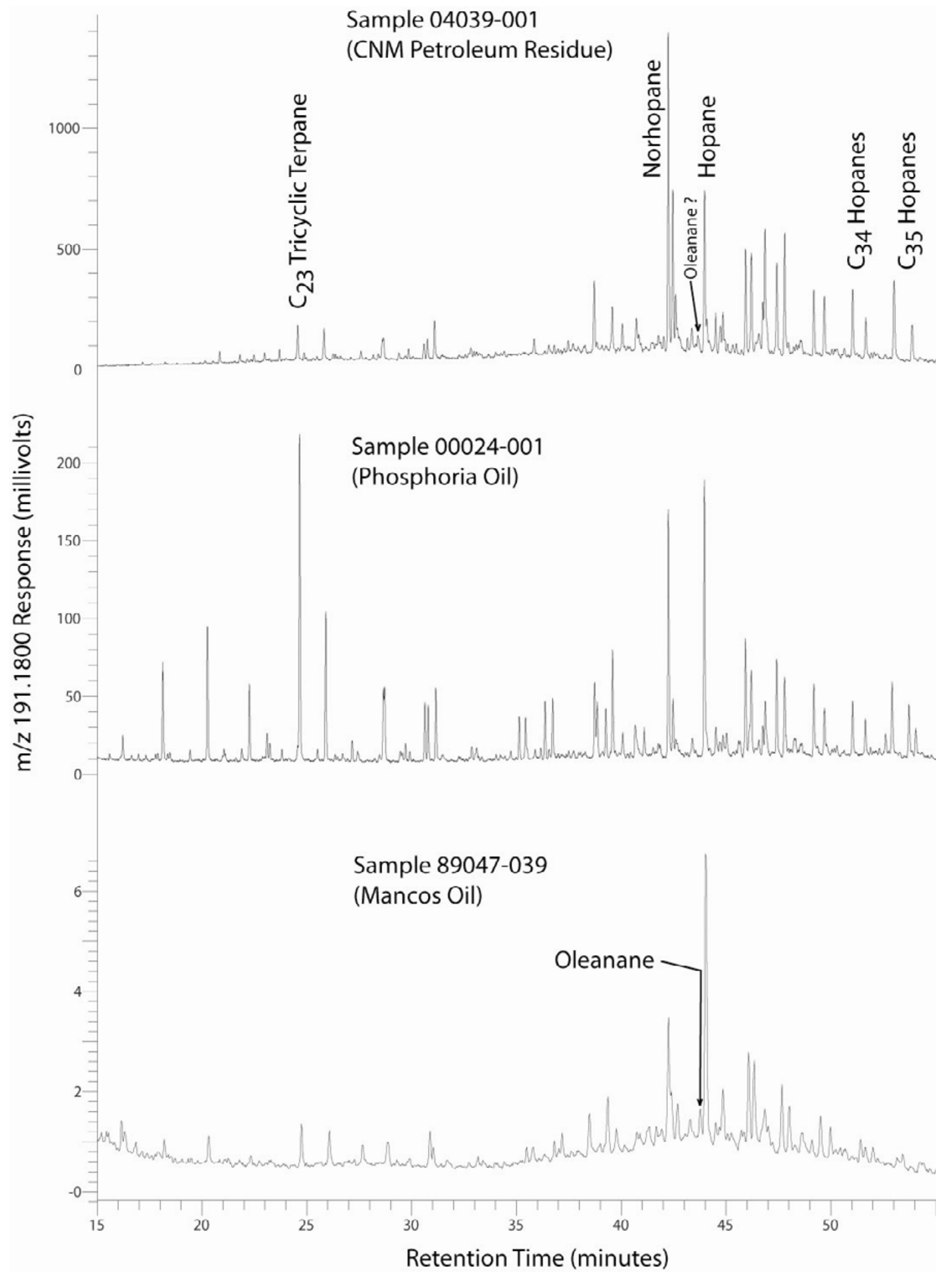

Figure 8. Terpane mass chromatograms of petroleum residue extract (Sample 04039-001) from the Entrada Sandstone in Colorado National Monument (CNM) and two representative crude oils from the Uinta-Piceance Province. 


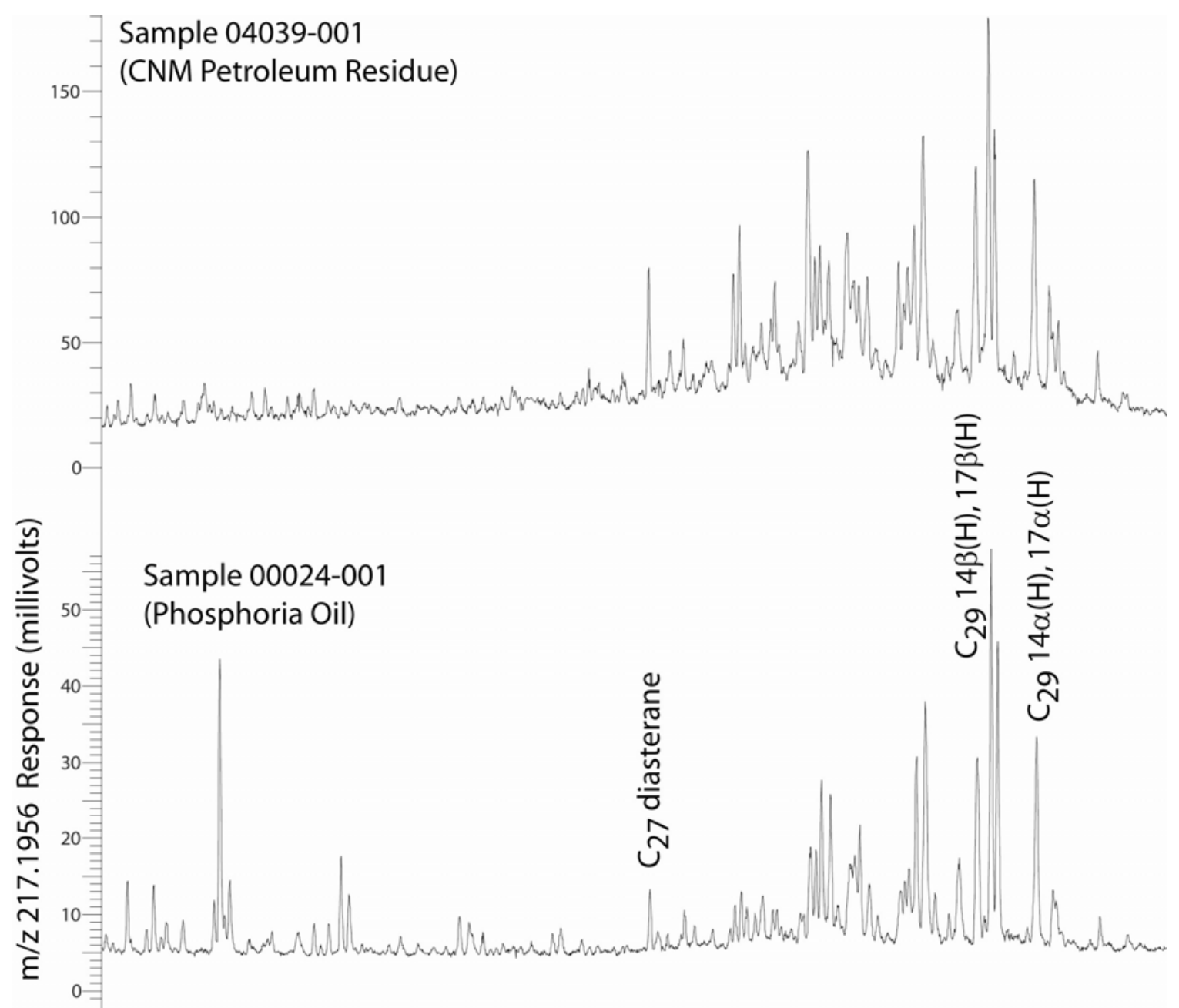

Sample 89047-039

(Mancos Oil)

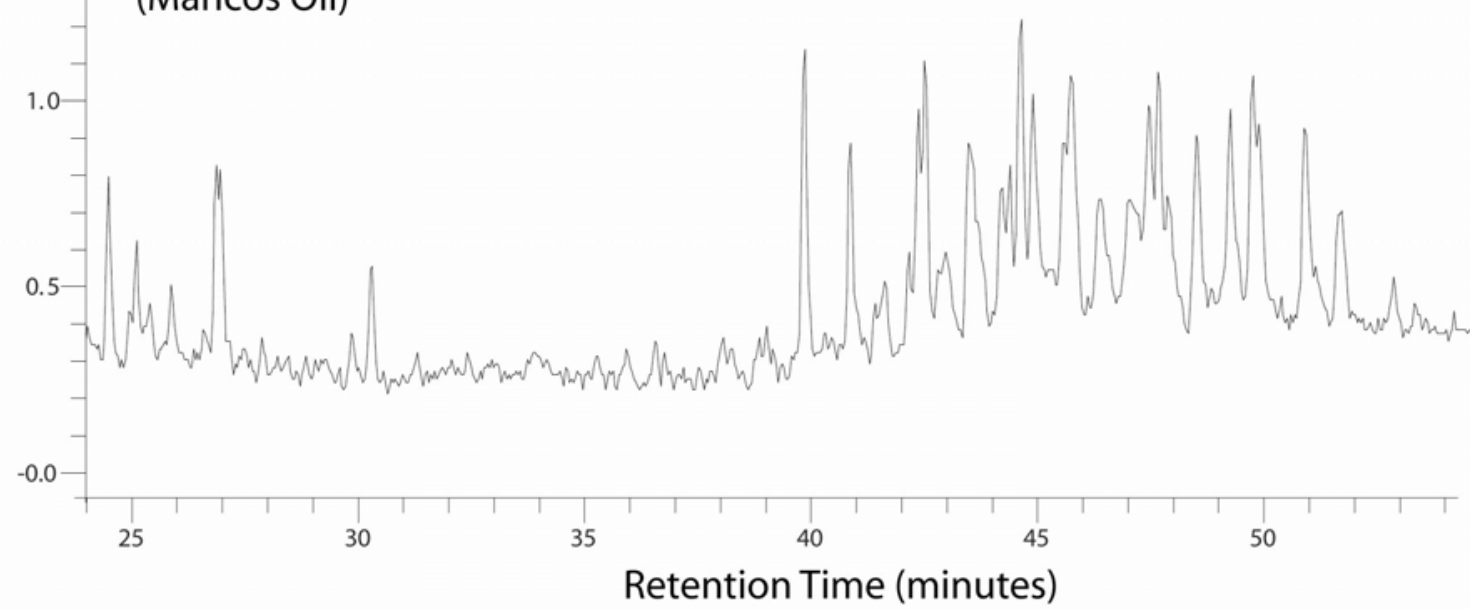

Figure 9. Sterane mass chromatograms of petroleum residue extract (Sample 04039-001) from the Entrada Sandstone in Colorado National Monument (CNM), and two representative crude oils from the Uinta-Piceance Province. 


\section{Discussion}

Phosphoria, Mancos, and Mesaverde oil types (Lillis and others, 2003) are the most likely candidates to have migrated into the Entrada Sandstone in the CNM. Gas chromatograms of the CNM extracts show that normal alkanes, acyclic isoprenoids, and light aromatic hydrocarbons are missing, indicating significant secondary alteration of the petroleum due to biodegradation and water washing (fig.5). Consequently, these chromatograms cannot be used for petroleum correlation. The high sulfur content (1.5$1.6 \mathrm{wt}$ percent, table 1) is due to biodegradation, and the sulfur content of the original oil was probably less than $0.7 \mathrm{wt}$ percent. Phosphoria oils in this area range from 0.5 to 1.4 weight percent sulfur, whereas Mancos and Mesaverde oils have less than 0.5 weight percent sulfur. The isotopic $\left(\delta^{13} \mathrm{C}\right)$ composition of the CNM stains is distinct from most oils in the area (Lillis and others; 2003), but the canonical variable (Sofer, 1984) values $(<-1.3)$ are similar to Phosphoria oils (fig. 4). These data indicate that the stains in this study may be genetically related to the Phosphoria oil type, with the shift to heavier $\delta^{13} \mathrm{C}$ values caused by biodegradation.

The biomarkers in the CNM extracts have been altered by biodegradation and water washing to varying degrees, making interpretations more difficult. Sample 04039001 is the least biodegraded, as indicated by having (1) the best resolved biomarker peaks in the extract gas chromatogram (fig. 5), and (2) more identifiable pentacyclic terpanes in the terpane mass chromatogram (fig. 6).

Sample 04039-001 contains low tricyclic terpane concentrations (for example, $\mathrm{C}_{23}$ tricyclic terpane $/$ hopane ratio $=0.22$ ) and possibly a small oleanane peak, similar to the Mancos oil type in the area (fig. 8). However, this sample contains high norhopane/hopane and $\mathrm{C}_{35} / \mathrm{C}_{34}$ hopane values that are similar to the Phosphoria oil type. 
The sterane composition most closely resembles the Phosphoria oil type, based on the relatively low $\mathrm{C}_{27}$ diasterane content, and high $\mathrm{C}_{29} 14 \alpha(\mathrm{H}), 17 \alpha(\mathrm{H})$ and $\mathrm{C}_{29}$ $14 \beta(\mathrm{H}), 17 \beta(\mathrm{H})$ sterane content (fig. 9).

\section{Conclusions}

The Entrada Sandstone in the Colorado National Monument (CNM) locally contains high concentrations of petroleum residue. These petroleum stains have been extremely altered by biodegradation and water washing; consequently, geochemical analyses are difficult to interpret. The least degraded sample most closely resembles the Phosphoria oil type, but some of the data correlate with the Mancos oil type. It is possible that the CNM residue is a mixture of both types, similar to oil in the Upper Jurassic Morrison Formation in Rangely field (Lillis and others, 2003).

\section{Acknowledgments}

We gratefully acknowledge Lisa Claussen, Dave Price, and Bruce Noble of the National Park Service for logistical support and access in the Colorado National Monument. David Allin and Bill Hood, Grand Junction, Colorado, provided insights and advice on the local geology and petroleum staining localities. Nicholas Battaglia and Augusta Warden aided in performing oil analyses at the USGS Central Energy Resources Organic Geochemistry Laboratory in Denver, Colorado. We also greatly appreciate thorough and constructive reviews by Joseph Hatch and Michael Pribil (USGS, Denver). Figure 1 was modified from a map produced by the National Park Service that was downloaded from the website http://www.nps.gov/hfc/carto/index.htm. 


\section{References Cited}

Lillis, P.G., Warden, A., and King, J.D., 2003, Petroleum Systems of the Uinta and Piceance Basins - Geochemical Characteristics of Oil Types, in Petroleum Systems and Geologic Assessment of Oil and Gas in the Uinta-Piceance Province, Utah and Colorado: U.S. Geological Survey Digital Data Series DDS-69-B, Chapter 3, 25 p., 7 figures, 1 table [CD-ROM].

Scott, R.B., Harding, A.E., Hood, W.C., Cole, R.D., Livaccari, R.F., Johnson, J.B., Shroba, R.R., and Dickerson, R.P., 2001, Geologic Map of Colorado National Monument and Adjacent Areas, Mesa County, Colorado: U.S. Geological Survey Geologic Investigations Series I-2740, 40 p., 1 map.

Sofer, Z., 1984, Stable carbon isotope compositions of crude oils: application to source depositional environments and petroleum alteration: American Association of Petroleum Geologists Bulletin, v. 68, p. 31-49.

USGS Uinta-Piceance Assessment Team, 2003, Petroleum Systems and Geologic Assessment of Oil and Gas in the Uinta-Piceance Province, Utah and Colorado: U.S. Geological Survey Digital Data Series DDS-69-B. 